DOI: $10.2478 /$ rpp-2014-0006

$\mathrm{PhD}$ (pedagogical sciences), OLESYA SADOVETS Associate professor of Khmelnytskyi National University Address: 11 Instytutska Str., Khmelnytskyi, 29016, Ukraine

Phone: 380 (067) 2883673

E-mail: lesya_82_82@mail.ru

\title{
FORMATION OF FOREIGN COMMUNICATIVE COMPETENCE OF ADULT IMMIGRANTS IN THE USA
}

\begin{abstract}
The necessity of forming foreign communicative competence of adult immigrants has been substantiated. The topicality of this issue for Ukraine has been defined. The experience of Global Talent Bridge, an initiative of World Education Services that is dedicated to helping skilled immigrants fully utilize their talents and education in the United States, concerning formation of adult immigrants' communicative competence has been analyzed. It has been defined that their research concerning organization and realization of contextualized education of adult immigrants aimed at the formation of communicative competence in the process of learning English as a second language has positive results and can be used as a basis for formation of communicative competence of Ukrainian emigrants. Principles of communicative approach to learning a language and the essence of learning for specific purposes have been defined. It has been determined that the education of adult immigrants aimed at the formation of communicative competence is sure to presuppose the availability of contextualized curriculum. The definition of contextualized curriculum has been given. It has been stated that in the process of its elaboration it is necessary to take into consideration the aim of immigrants' language learning, the priority of fluency and proficiency of language, principles of learning a foreign language by adults, communicative aspect of learning a language, the necessity of forming skills of Basic Interpersonal Communication and Cognitive Academic Language Proficiency; usage of special tests for checking skills of communicative competence, different types of lessons for proficient knowledge of everyday English as a second language.

Key words: communicative competence, contextualized education, contextualized curriculum, English as a Second Language, adult immigrants, English for specific purposes.

\section{INTRODUCTION}

Under the modern conditions of social and labor mobility of people, their migration abroad for better employment and improvement of economic and financial state the issue of fluent mastering of the target language by migrants is becoming more urgent. For Ukraine this problem is especially up to date as many Ukrainians migrate abroad yearly. Thus, proficient knowledge of the target language by adult emigrants is the necessary condition of their social and professional progress. It is known that people immigrating into other countries with a good knowledge of a target language have much more chances to get a good job than those who don't speak the target language. At present day emigrants are aware of the importance of fluent and proficient knowledge of a target language, they are ready to master the language and undergo special courses and education. But they often come across a range of problems, caused by lengthy courses, inconsistent teaching methods
\end{abstract}


of foreign language, inappropriate content of the learning materials, presented within accessible programs of foreign language learning. At the same time even good programs of foreign language learning that provide the opportunities to achieve proficient level of knowing a language, don't always provide adult emigrants with "communicative competence", which is the main aim of their education and precondition of their successful professional activities.

\section{THE AIM OF THE STUDY}

To analyze the American experience, namely of Global Talent Bridge - an initiative of World Education Services that is dedicated to helping skilled immigrants fully utilize their talents and education in the United States - of organizing the learning aimed at the formation of foreign communicative competence of adult immigrants that can be used as a basis for foreign communicative competence of Ukrainian emigrants.

\section{THEORETICAL FRAMEWORK AND RESEARCH METHODS}

The issue of communicative competence in scientific and pedagogical literature is not new. It was studied in the works of many home and foreign scientists (S. Amelina, L. Anpilohova, Yu. Emel'yanov, O. Fedorov, V. Ivanov, T. Kolbina, N. Koroleva, D. Louise, A. Markova, A. Moskalenko, A. Panfilova, L. Petrovska, A. Serhiyenko, L. Stolyarenko, $\mathrm{Yu}$. Zhukov etc.). Formation of foreign communicative competence was studied in the works of I. Berman, I. Batsenko, V. Borshchovetska, V. Bukhbinder, R. Ellis, V. Hnatkevych, H. Kytaihorodska, V. Korostylyov, M. Louise, E. Miroshnychenko, I. Nation, D. Norman, Yu. Passov, N. Schmitt, S. Shatilov, O. Tarnopolskyi, W. Widdowson and others. But the problem of such competence formation at the courses of foreign languages for adult immigrants is not sufficiently studied. In the result of our own scientific research it has been defined that some positive experience of teaching English as a foreign language (further - ESL) for adult immigrants, aimed at the formation of their communicative competence, belongs to the USA. Special attention was given to Global Talent Bridge - an initiative of World Education Services - that is dedicated to helping skilled immigrants fully utilize their talents and education in the United States. Their research and its results give some valuable clues concerning formation of foreign communicative competence of Ukrainian adult emigrants.

The research of the article was conducted on the basis of such research methods as comparative analysis, interpretative-analytical method with application of analysis, synthesis, systematization and comparison, content-analysis, structural and systemic analysis, and theoretical summarization.

RESULTS

ESL learning for adult immigrant in the USA is based on the principles of adult education and takes into consideration special needs and demands of the adults to language learning. On the basis of such needs general characteristics of the process of learning a foreign language by adults have been defined:

1) in learning a foreign language adults always pursue some purpose;

2) language is a social process that presupposes social interaction;

3) foreign language learning is improved if its teaching is carried out on the level higher than the level of a learner's knowledge;

4) perfection of the foreign language knowledge demands concentration, active participation, practice and commitment of those who study;

5) a language is a multidimensional phenomenon and its mastering demands different types of interaction in different kinds of activities;

6) knowledge of a foreign language improves in the process of doing interactive tasks requiring cognitive commitment; 
7) knowledge of a foreign language improves if it has direct relation to some topic or context (Johns \& Price-Machado, 2001).

The last principle is especially important for learning ESL and is a basis for contextualized learning that is the learning that is based on the context of real life. Such learning is also known as Functional Context Education (further - FCE). Contextualized education or FCE requires elaboration of "contextualized curriculum" that is such a curriculum that presupposes usage of authentic materials, phrases and lexical units peculiar to some context (for example, for engineering, medicine, business administration etc.). Only such courses and programs of education aimed at the formation of contextualized cognitive skills for a definite branch of activity will help adult immigrants in the USA become high qualified workers and employees at the labor market the same as native Americans (Adult ESL Classroom Strategies and Lesson Ideas, 2011).

It is necessary to admit that this approach to learning a language with the help of FCE is not new. It was used in late $60 \mathrm{~s}$ and early $70 \mathrm{~s}$ for a language training of militaries in the branch of technology during the war in Vietnam. Since that time large scale programs of staff training funded by the Labor Department of the USA are based on this approach.

Main principles for using FCE to master ESL are the following:

- adult learning has to be fully consistent, take into consideration the content of previous education, peculiarities of a work place, professional knowledge;

- learning materials, means of learning, equipment in the classroom have to be directly related to professional activities of learners and be used after the end of the learning process;

- communicative skills of the English language are improved together with content and information processing skills, discursive, intercultural and socio-linguistic skills;

- correct assessment of the process and results of the education requires special assessment of its context and content (Spruck-Wrigley \& Powrie, 2002).

In the practice of teaching English these principles formed the basis for elaboration of principles of Communicative Language Teaching Approach (further - CLT). FCE and CLT are used together and complement each other. In 1970s CLT gave start to the epoch of changes and innovations in teaching English, changed the understanding of the very essence of the language, process of its learning and methods of teaching. These changes had considerable influence on the choice of effective content of education and ESL learning materials used in the classroom. These changes helped elaborate contextualized curriculum to correspond narrow demands and needs of learners (Richards, 2008).

CLT approach is based on the set of rather general principles which don't contradict one another. Its implementation presupposes different forms of class work and different contexts. Generally accepted CLT principles are as follow:

1) communicative competence is the aim of learning a language;

2) learners learn a language to have possibilities to transmit real life messages;

3) authentic and consistent communication is the aim of the class work;

4) fluency and accuracy are two important dimensions of communication;

5) communication presupposes integration of different language skills;

6) learning is a gradual process that is characterized by trials and mistakes (Adult ESL Classroom Strategies and Lesson Ideas, 2011).

CLT approach became widely used as a type of communicative, contextualized language learning or so-called education of specific purposes. Such kind of education must presuppose the availability of contextualized curriculum.

At present day there many curricula worked out for specific purposes. They are presented in Table1(Adult ESL Classroom Strategies and Lesson Ideas, 2011): 


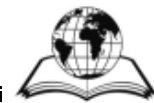

\begin{tabular}{|c|c|c|c|c|}
\hline $\begin{array}{c}\text { Content-Based } \\
\text { Instruction }\end{array}$ & $\begin{array}{c}\text { Cooperative } \\
\text { Language } \\
\text { Learning }\end{array}$ & $\begin{array}{c}\text { Task-Based } \\
\text { Instruction }\end{array}$ & $\begin{array}{c}\text { Project-Based } \\
\text { Instruction }\end{array}$ & $\begin{array}{c}\text { English } \\
\text { For Special } \\
\text { Purposes }\end{array}$ \\
\hline $\begin{array}{c}\text { English } \\
\text { Por Academic } \\
\text { Purposes (EAP) }\end{array}$ & $\begin{array}{c}\text { English For } \\
\text { (EMP) }\end{array}$ & $\begin{array}{c}\text { English } \\
\text { English For } \\
\text { the Law (ELP) } \\
\text { and Economics } \\
\text { (EBE) }\end{array}$ & $\begin{array}{c}\text { English } \\
\text { For Science } \\
\text { and Technology } \\
\text { (EST) }\end{array}$ \\
\hline $\begin{array}{c}\text { For Diplomacy } \\
\text { (ED) }\end{array}$ & $\begin{array}{c}\text { Vocational English } \\
\text { as a Second } \\
\text { Language (VESL) }\end{array}$ & $\begin{array}{c}\text { English } \\
\text { For the } \\
\text { Construction } \\
\text { Industry (ECI) }\end{array}$ & $\begin{array}{c}\text { English } \\
\text { For Restaurant } \\
\text { Workers }\end{array}$ & $\begin{array}{c}\text { Fonglish } \\
\text { and Hospitality } \\
\text { Workers }\end{array}$ \\
\hline
\end{tabular}

The aim of all ESL lessons, especially those directed onto the work of adult immigrants, according to the first principle of CLT, is communicative competence. It presupposes the ability to communicate or react to messages of the native speakers in real life conditions. Here the stress is not on the correctness of the communication form or grammar rules, but on the situations of communication. Progress in learning ESL is evident if the learners are involved into the interaction and meaningful communication. Meaningful communication is the result of students' processing of the educational content, which is relevant, purposeful, interesting and fascinating (Sticht, 2000).

Communicative competence of adult immigrants studying ESL includes: grammar competency, i.e. the level of mastering linguistic knowledge of lexical material, grammar, pronunciation, spelling and word formation; socio-linguistic competency, i.e. the level of correct understanding the language in different social contexts, knowledge of language templates, such as persuasion, excusing, description; discursive competency, i.e. the ability to combine ideas for achieving the unity of thoughts and the form of its expression, that is higher than the level of a simple sentence; strategic competency, i.e. the ability to use some strategies (for example, gestures) to transmit an unknown word or overcome limitations in the language knowledge; ability to use a language of gestures (non-verbal behavior).

Teaching ESL aimed at the formation of communicative competence has to be organized by an instructor (teacher) who can work out an appropriate curriculum taking into consideration the prior aspect of learning a language (whether it is social or academic); the aim of learning (whether it is formation of Basic Interpersonal Communication Skills (further-BICS) or mastering Cognitive Academic Language Proficiency (further-CALP) (Schellekens, 2001).

Professor Jim Cummins from the University of Toronto was the first to differentiate social and academic English. His research was based on the work with immigrants' children. In the result of the research he came to conclusion that BICS is a basic communicative fluency of communication that is peculiar to all native speakers and includes language skills necessary in different social contexts for everyday interaction with other people. Cognitively social English or BICS doesn't require a lot of efforts, is contextualized and used in informal environment, let us say at the sports ground or at the café. Immigrants' children often master BICS easily communicating with native speakers' children. But the majority of adults have problems here if they are not given strict instructions about how to obtain the skills of basic interpersonal communication (Richards, 2008).

Mastering of cognitive academic language in its turn presupposes formal academic studying and ability to comprehend and use the language as instrument for learning. 
Mastering of the academic language includes not only the understanding of the meaningful lexical material, but skills of comparison, classification, synthesis, evaluation and summarizing. Researchers claim that knowledge, ideas and notions which learners acquire within a native language automatically are transferred into a foreign language. Thus, the majority of adults learning English, especially high qualified and educated immigrants, tend to quick and proficient mastering of CALP, because these skills are transferred into English from their native language. What they lack is basic skills of interpersonal communication which are formed together with sociolinguistic, strategic and discursive competencies. Such competencies must be formed directly during the teaching process in a classroom with the use of contextualized communicative curriculum. It is the lack of interpersonal contextualized communication that slows down the process of immigrants' obtaining a working place and their professional development (Spruck-Wrigley \& Powrie, 2002).

Besides, another question of how to teach correct communication and assess it arises. Speaking has always been the priority of teaching a foreign language, but the essence of speaking skills and the methods of their formation in the process of teaching changed with the introduction of communicative approach to teaching a language. Formation of communicative competence requires development of communicative syllabi and contextualized curriculum. Learners have to be able to communicate culturally in the environment of the target language (Johns \& Price-Machado, 2001). Now it is evident that models of oral communication cannot be based only on the intuition of applied linguists and authors of handbooks. They have to be based on the results of analysis of the real communicative situations. The results of analysis of the real communicative situations conducted by American methodologists and linguists gave the possibility to formulate the following conclusions:

- for fluent communication on the level of colloquial English "chunks of communication" and not individual lexical units have to be predominant in the process of its teaching (phrases and statements like the other day, when I got a call, I got a real surprise etc.);

- set expressions and conversational clichés are very frequent in the process of learning English as a foreign language (for example is that right, you know what I mean, uh-huh, no kidding etc.);

- oral speech of learners has to be interactive and flexible and presuppose dialogues, remarks to the statements and messages, presentation of some topic etc.;

- strict differentiation of interactive communication (aimed at a person) and operational (aimed at the transmission of the message) is necessary (Sticht, 2000).

Taking everything into consideration one important issue arises: how can a teacher discern if his/her students begin to acquire communicative competence. It is clear that the results of a grammar test will not give answers to that question. Results of standardized tests of ESL knowledge such as TOEFL, TOEIC, IELTS, CASAS, BEST plus and others are important without doubts but for education of adult immigrants in the USA, who learn English, the results of a so-called test for the language knowledge at non-proficient level «Layman's Litmus Test» are more important. This test is done by immigrants who work as contractors, builders, receptionists, supervisors, secretaries, hotel administrators (Adult ESL Classroom Strategies and Lesson Ideas, 2011). Positive results of this test testify about positive changes in acquiring communicative skills, about the first features of the communicative competence formation. In their turn, ESL teachers can define when communicative competence of their students begins to be formed with the help of such students' abilities:

1) to express genuine interest, anxiety, compassion, concern (e.g. when they are informed about a colleague whose close member of the family has just passed away); 
2) to excuse oneself, explain the reason of being late (even when it is necessary to make it up) etc.;

3) to talk politely and relevantly at a business meeting, before the beginning of the meeting etc.;

4) to know how to invite to the lunch, party etc.;

5) to be able to ask questions, not just to give answers;

6) to use ordinary phrases, set expressions, every day phrases and phrases that make the speech natural and easy (for example: See you soon; I think so; I will get back to you as soon as I can; That sounds great etc.);

7) to freely use intonation of the target language in a natural and easy way, according to the content that is in the sentence (for example, "Sorry?» with raised intonation for the expression of the meaning "I am sorry, I didn't understand. Could you repeat please?")

8 ) to use correctly conversational clichés in a dialogue and conversational introductory phrases in a conversation with a person face-to-face or over the phone, correctly and relevantly use pauses in a conversation, correctly start a conversation, change the topic of the conversation tactfully, understand when someone wants to end the conversation etc. (Richards, 2008).

A good example of a contextualized lesson of ESL aimed at the formation of communicative competence of adult immigrants is a strategy of using so-called "introductory conversational set expressions". They are used in teaching English for the formation of non-native speakers' oral speech skills. The use of such phrases in practice of communication testifies about proficient level of mastering English as a foreign language. Introductory conversational set expressions are the basis for making questions about one's opinion, request to explain something, for paraphrasing, persuasion, summarizing, polite interruption of the conversation, refusal from the offer (suggestion), avoiding direct answer, beginning of the conversation, end of the conversation, talking about oneself, one's work, giving suggestion, accepting suggestions, refusal from the suggestion, asking about appropriateness of some action etc. (Adult ESL Classroom Strategies and Lesson Ideas, 2011).

To learn such phrases learners have to work in pairs and read the list of phrases, ticking those which they have already seen or heard. The teacher has to encourage the learners to discuss phrases which are unknown or not clear and encourage them to ask about the meaning of those phrases. Then learners have to make up ten sentences with different phrases, read them in class and discuss their effectiveness and relevance of using these introductory phrases.

One more idea for a contextualized lesson is the use of gesture language at a working place. It is very important because communicative competence includes elements of sociolinguistic and strategic competencies, which presuppose the knowledge of appropriate nonverbal language and gesture language. These skills are especially important at a working place for correct understanding of colleagues. They should be formed and practiced because gesture language differs in different countries. Some gestures are inappropriate at a working place. For example, if a person is standing too close to another person, it can be perceived as the expression of aggression, intimidation or attack; if a person speaks quietly or avoids eye contact, that can be perceived as the expression of shyness or lack of confidence; if a person smiles rarely then it may seem that the person is unfriendly (Schellekens, 2001). It's important to remember about meaning of some gestures and non-verbal behavior. Thus, when a person bends his/her head to one side, it means being interested or sympathizing; when a person looks into the floor, it means he/she is shy and dishonest; if the arms are 
crossed, the person protects himself/herself and disagrees; restlessness and fussiness are evidence of nervousness; rolling up the eyes is the sign of disrespect.

To teach students who are adult immigrants to understand non-verbal behavior, such a task can be given to them in classroom: they have to get acquainted with a suggested situation and give answers to the given questions. Let us take the following situation as an example: While Ukrainian immigrant Maksym (or any other immigrant) is telling his boss about his plans for the weekend, he notices that his boss practically is not looking into his eyes and all the times is glancing at the clock. Every several seconds he is looking at the monitor of his computer. The questions: 1. What gesture language did the boss of Maksym use? 2. Up to you, what does this non-verbal behavior testify about? 3. How should Maksym react to such a behavior of his boss? (Adult ESL Classroom Strategies and Lesson Ideas, 2011).

\section{CONCLUSIONS}

So, it is quite clear that in modern time immigrants abroad should know the target language proficiently, their level of the language knowledge must be on a high level especially in their professional branch. At the same time special attention should be paid to formation of communicative aspect of mastering a language with the gradual formation of foreign communicative competence. The experience of Global Talent Bridge, an initiative of World Education Services that is dedicated to helping skilled immigrants fully utilize their talents and education in the United States, concerning formation of adult immigrants' communicative competence, proved to be effective and can be used as basis for training Ukrainian emigrants to master the target language on the level sufficient for obtaining a good working place and professional development. It has been defined that for communicative competence formation it is necessary to organize the education on the basis of contextualized curriculum. In the process of its elaboration the following should be taken into consideration: the aim of learning a foreign language by immigrants; focus on the fluency and proficiency of a language mastering; principles of learning foreign languages by adults; communicative aspect of a language (CLT); importance of forming skills of basic interpersonal communication (BICS) and mastering the cognitive academic language (CALP - Cognitive Academic Language Proficiency); focus on communicative competence; using relevant special tests for checking the skills of communicative competence; different types of lessons for proficient mastering of colloquial English as a foreign language.

\section{REFERENCES}

1. Adult ESL Classroom Strategies and Lesson Ideas. (2011). Retrieved 09.09.2013 from: http://www.globaltalentbridge.org/toolkit/pdf/CH3_ESLStrategies.pdf

2. Johns, A., Price-Machado, D. (2001). English for Specific Purposes: Tailoring Courses to Student Needs and to the Outside World. In: Celce-Murcia, M. (Ed.). Teaching English as a Second or Foreign Language, p. 112-113. Heinle and Heinle.

3. Richards, J. (2008). 30 Years of TEFL/TESL: A Personal Reflection. Singapore: SEAMO Regional Language Centre.

4. Schellekens, Ph. (2001). English Language as a Barrier to Employment, Education and Training. UK: The Department for Education and Employment of the United Kingdom.

5. Spruck-Wrigley, H., Powrie, J. (2002). What Does It Take for Adults to Learn?. USA: TESOL.

6. Sticht, T. (2000). Functional Context Education: Making Learning Relevant. Retrieved 09.09.2013 from: http://library.nald.ca/item/58939 